\title{
In vitro experimental evaluation of wound and burns healing capacity after exposure to salty microclimate from Dej and Cacica
}

\author{
- Constantin Munteanu ${ }^{1}$, Diana Munteanu, Iuri Simionca, Mihai Hoteteu
}

\section{Abstract}

Objective: To investigate the influence of Cacica and Dej salt mines microclimate on the morphology and electrophoresis protein expression of in vitro dermal fibroblasts from hypodermic tissue of Wistar rats in normal conditions and after experimental induced wounds and burns.

Materials and methods: Dermal fibroblast cultures were obtained from hypodermic tissue collected from Wistar rats. Grow in cultures derived fibroblast monolayer is attached to the cultivation flask. Before initiation of cultures, Wistar rats weighing 75-100 g were separated into three groups: control, wounds and burns. Five animals from each group were sent to Cacica and Dej salt mines, for 14 days and kept in saline environment, as in speleotherapy.

Results: Speleotherapy applied to Wistar rats caused significant differences in cell morphology and electrophoretic expression of dermal fibroblasts in primary culture completed. The data obtained confirm the therapeutic effects of speleotherapy compared with experimental data from control animals.

Conclusions: The results of this study indicate that speleotherapy induces changes in morphology and protein expression of in vitro dermal fibroblasts and therapeutic effects of these changes are present in the wounds and burns cases.

Keywords : speleotherapy, dermal fibroblasts, wounds and burns, salt mine.

\footnotetext{
${ }^{1}$ Corresponding author: Constantin Munteanu, tel./fax: +40213186458, e-mail: constantin2378@yahoo.com, Mmailing address: B-dul Ion Mihalache, nr.11A, District 1, cod 79173, Bucharest, Romania, http://www.cell-culture.xhost.ro/
} 


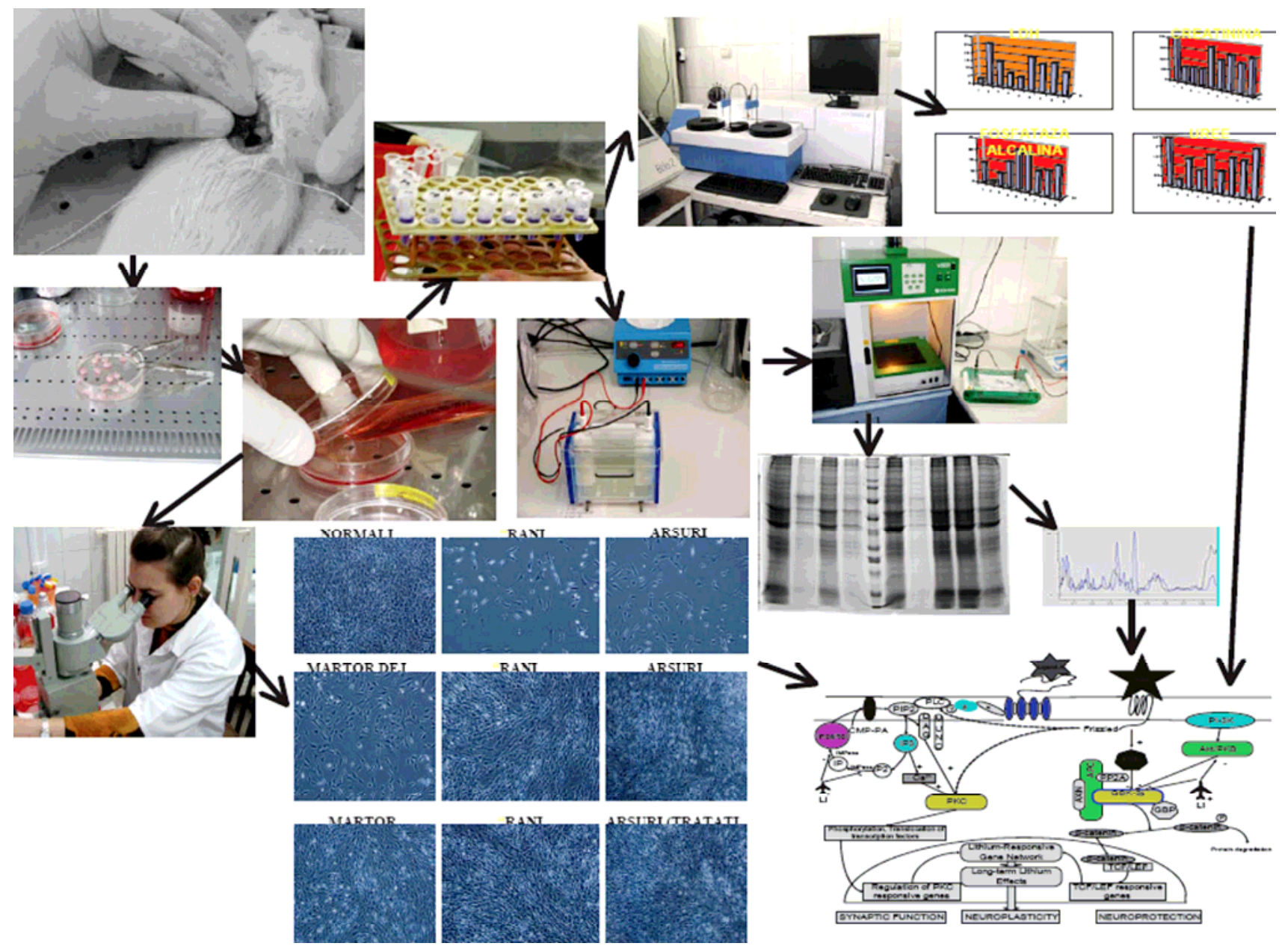

\section{INTRODUCTON}

The skin is the primary interface between body and environment. Spectrum in which aggression is likely included skin conditions caused by chemical and microbial, thermal and electromagnetic radiation and mechanical trauma. Skin damage is the consequence of the invasion of pathogenic microorganisms, which may affect human life.

Wound healing is a restorative natural responded to tissue damage - which consists of a cascade of cellular events whose nature depends on the characteristics of the wound. There are acute injuries resulting from surgery, penetration of sharp objects, amputation of phalanx, fray, burns, animal bites, etc.. and chronic wounds as arterial ulcers, venous ulcers, limfedemul, pressure ulcers and neuropathic ulcers.
Regenerative medicine is widely seen as one of the next revolutions in medical treatment. It draws heavily from the fields of tissue science, biology, biochemistry, physics, chemistry, materials science, applied engineering and other fields and is a highly interdisciplinary new discipline. The general aim of regenerative medicine is to repair, replace or regenerate lost or damaged tissues and organs in vivo through techniques that stimulate them into healing themselves. Tissues and organs can also be grown in vitro for subsequent implantation into the body.

Using skin cell cultures to verify the therapeutic properties of saline mines medium, described as speleotherapy, represents an innovative and scientific new way to establish the medical methodology of preventing, treating and recovery of patients with various dermatological problems. 


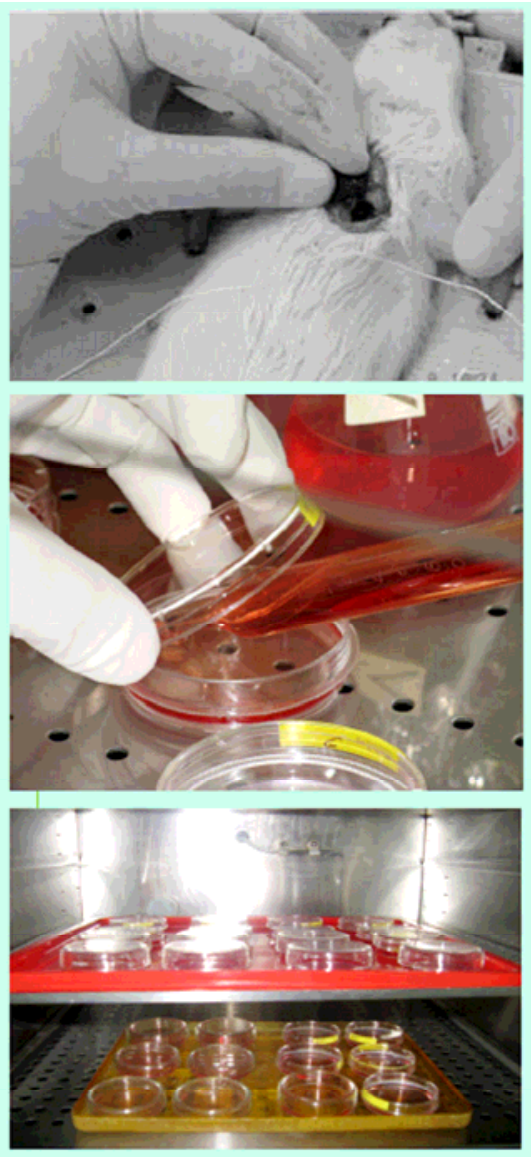

\section{MATERIALS AND METHODS}

Materials

Phosphate Buffer Solution (PBS: $\mathrm{NaCl}$ $0,13 \mathrm{M}+\mathrm{KCl} 2,6 \mathrm{mM}+\mathrm{Na}_{2} \mathrm{HPO}_{4} \times 12 \mathrm{H}_{2} \mathrm{O}$ $\left.8 \mathrm{mM}+\mathrm{KH}_{2} \mathrm{PO}_{4} 1,4 \mathrm{mM}\right) ;$ HAM-F12 culture medium (Sigma); penicillin $100 \mathrm{U} / \mathrm{ml}$, streptomycin $100 \mu \mathrm{g} / \mathrm{ml}$; neomycin $50 \mu \mathrm{g} / \mathrm{ml}$ (Sigma); fetal bovine serum (Sigma).

Animal model - Wistar rats with experimental wounds and burns: Wistar rats of 75-100 g weight were subjected to burns and wounds of $1 \mathrm{~cm}$ square on the back.

Dermal fibroblasts culture

After anaesthesia with chloroform, rats were killed. After hair removing, a patch of 1 $\mathrm{cm}^{2}$ of skin was detached en bloc in a laminar flow hood using sterile technique and put into ice-cold sterile Phosphate Buffer Solution (PBS: $\mathrm{NaCl} 0,13 \mathrm{M}+\mathrm{KCl} 2,6 \mathrm{mM}+\mathrm{Na}_{2} \mathrm{HPO}_{4}$ $\left.\mathrm{x} 12 \mathrm{H}_{2} \mathrm{O} 8 \mathrm{mM}+\mathrm{KH}_{2} \mathrm{PO}_{4} 1,4 \mathrm{mM}\right) .1 \mathrm{~mm}$ tissue pieces were suspended in $0.125 \%$ trypsin and $0.001 \%$ DNase and repeatedly stirred for 6 minutes and centrifuged at $1000 \mathrm{~g}$. The pellet was resuspended in HAM-F12 medium with $4500 \mathrm{mg} / 1$ glucose, $25 \mathrm{mM}$ HEPES, $100 \mathrm{U} / \mathrm{ml}$ penicillin, $100 \mu \mathrm{g} / \mathrm{ml}$ streptomycin and 50 $\mu \mathrm{g} / \mathrm{ml}$ neomycin and $10 \%$ fetal bovine serum.

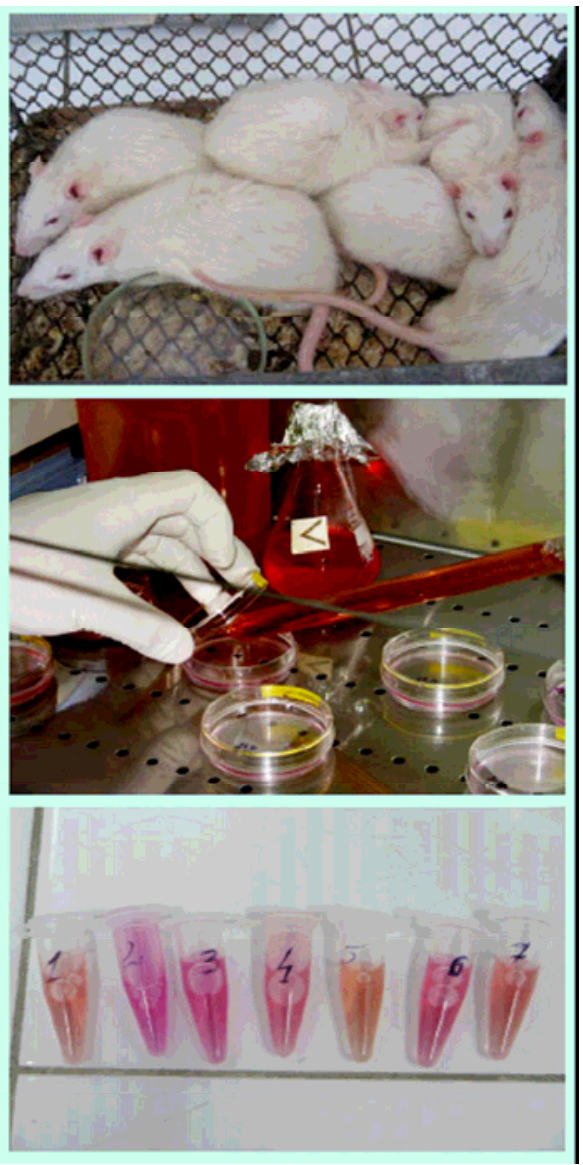

Phase Contrast Microscopy

Phase contrast microscopy, first described in 1934 by Dutch physicist Frits Zernike, is a contrast-enhancing optical technique that can be utilized to produce high-contrast images of transparent specimens, such as living cells.

\section{SDS-PAGE Electrophoresis}

The proteins electrophoresis from the total homogenate has as the purpose to establish the changes, which are revealed at the proteic level of fibroblasts cultures obtained from rats held on speleotherapy.

The proteins electrophoresis in gel of polyacrylamide was done in the denaturated conditions in the conformity with the techniques described by Laemmli (1979). The cultures have been washed with PBS, curetted from the culture plate and lyzed in buffer containing $0,5 \mathrm{M}$ Tris- $\mathrm{HCl}, \mathrm{pH} 6,8+0,05 \%$ $\mathrm{BPB}+10 \%$ glycerol + SDS $10 \%$.

Analysis with GeneTools version 4 software from SynGene of each track of the electrophoresis allowed us to compare the profiles of the total proteins expression. 


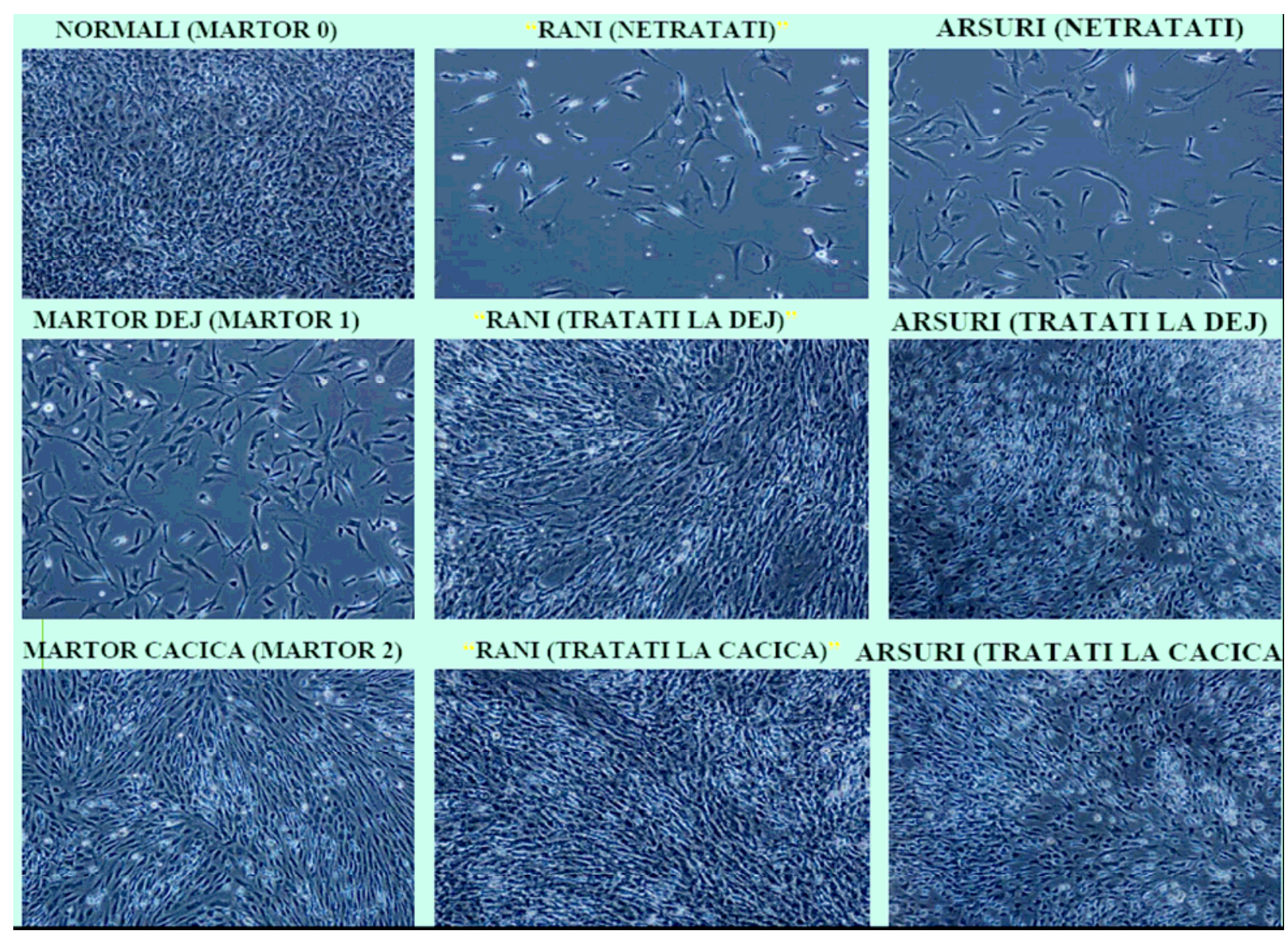

\section{RESULTS and DISCUTIONS}

Control dermal fibroblasts culture of 7 days has a heterogenic aspect with a high preconfluence level. The cell division is to a high level and the cell morphology shows a typical microscopic view, described in the specific literature. There are mainly two types of cells: epithelial and fibroblastic cells.

Dermal cells cultures of 7 days obtained from negative control untreated rats with wounds and burns presents many morphological changes from the control skin cell culture, being observed an sensible number reducing of dermal fibroblasts in culture, the diminished cellular dividing frequency and an accentuated cellular morphopathology of the cells in culture. After 7 days of culturing, the preconfluence level is much lower than in the Biobase control case.

Dermal fibroblasts cultures of 7 days obtained from positive control rats treated by speleotherapy in Cacica Salt Mine shows an improvement of the morphological parameters of the cells comparative with the cultures obtained from negative control rats. By phase contrast microscopy, it is possible to observe a rising of the cells number.
Dermal fibroblasts cultures of 7 days obtained from rats with wounds and burns and treated by speleotherapy in Dej and Cacica Salt Mines show an improvement of the morphological parameters of the cells comparative with the cultures obtained from negative control rats. It is observed the rising of the cell population density and that of cell viability.

Following electrophoresis, the gel was stained with Coomassie Brilliant Blue R-250, that allowed visualization of the separated proteins. After staining, different proteins appeared as distinct bands within the gel (Towbin et al., 1979).

The morphological observations are confirmed by the electrophoretic analyses, which demonstrate through rising of the expression of many proteins and of total protein amount that the exposure of animals to the saline medium from Dej and Cacica Salt Mines is reversing the cells morphopathology of dermal fibroblasts in cultures. 


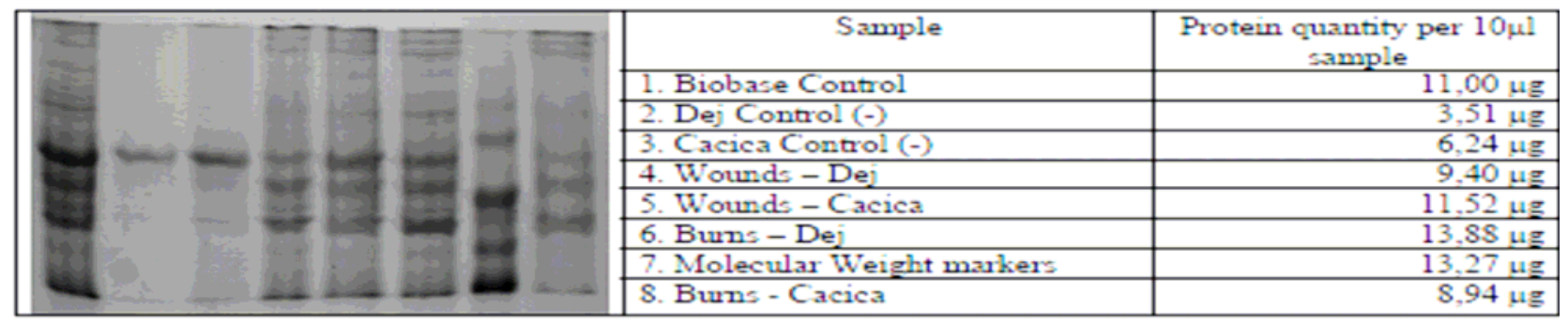

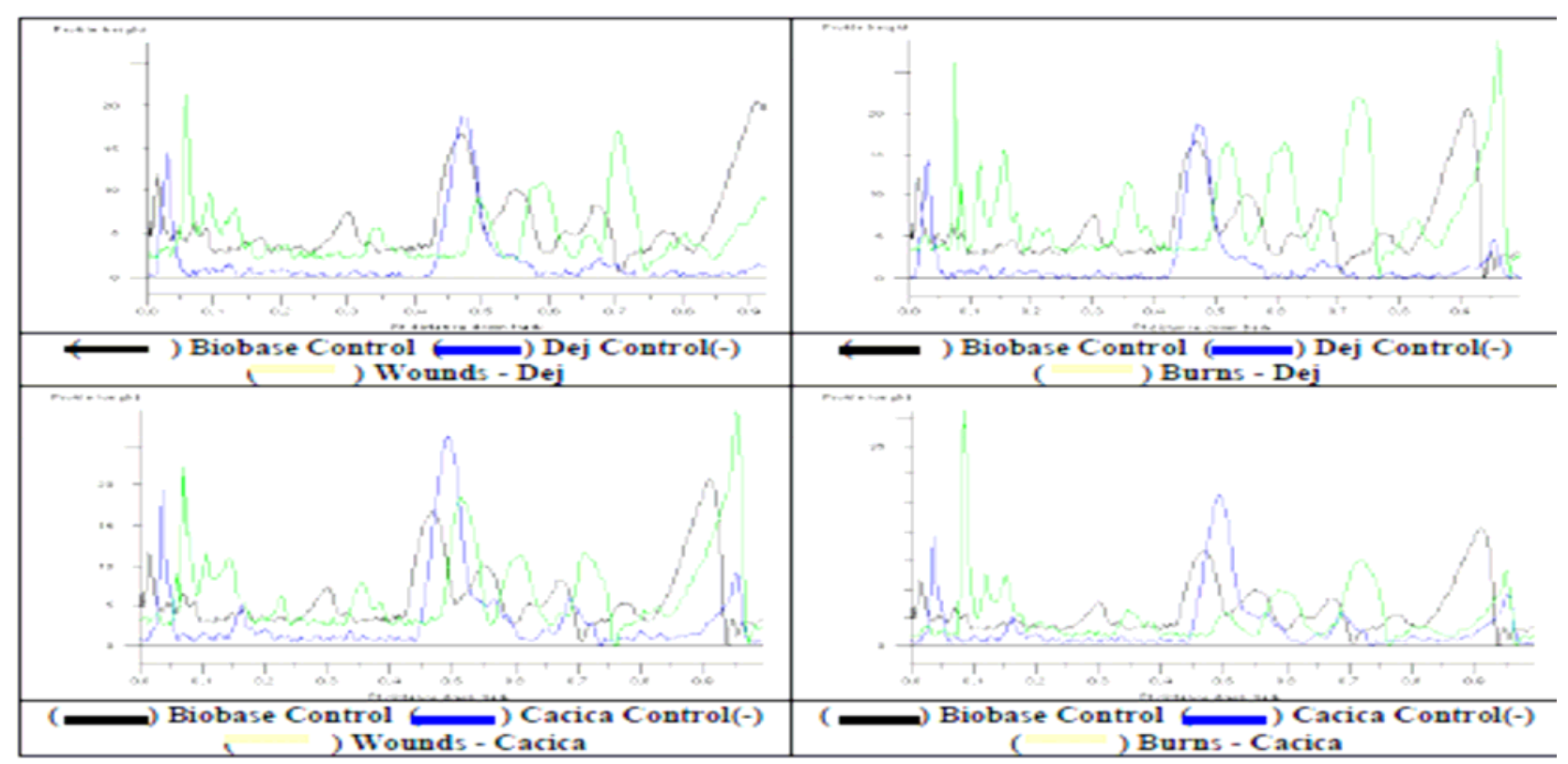

\section{Acknowledgments}

This study will be finished in 2011 and is granted by The National Authority for Research- CNMP, contract nr. 42120/2008, project: Complex of medical-biological study of potential therapeutic factors related to salt mines and karst environments for effective use in health and balneo-turism; development and modelling solutions of these factors, coordinated by Dr. Iuri Simionca.

\section{References}

1. Flaxman A. - cell identification in primary cell cultures from skin, In vitro, vol.10, no $1 \& 2,1974$

2. Foster Judith Ann, Celeste B.R., Miller M.F. - Pulmonary Fibroblasts: an in Vitro Model for Emphysema, The Journal of Biological Chemistry, Vol. 265, No. 26, 1990, p. 15544-15549;

3. Laemmli U.K. (1979) Cleavage and structural proteins duting the assembly of the head of bacteriophage $\mathrm{T}_{4}$. Nature 227: 680-682.

4. Neagos D. - Teza de doctorat: MODELE CELULARE DE STUDIU IN VITRO A
MECANISMELOR MOLECULARE CARE STAU LA BAZA REPARARII LEZIUNILOR PIELII, Universitatea din Bucuresti, 2007

5. Towbin H., Staehelin T., Gordon J. (1979) Electrophoretic transfer of proteins from polyacrylamide gels to nitrocellulose sheets: Procedure and some applications. Proc. Natl. Acad. Sci. USA 76: 4350-4354.

6. Simionca I., Grudnicki N., Buturuga A., Hoteteu M., Kiss J., Oprina A. Speleoterapia bolnavilor cu astm bronşic non-sever prin intermediul factorilor terapeutici din salina Slãnic Prahova, Editura "George Tofan", Suceava 2009, ISBN 978-973-1862-87-3

7. Sugiura H., Liu X., Duan F., Kawasaki S., Togo S., Kamio K., Wang X.Q., Mao 1., Ahn Y., Ertl R.F., Bargar T.W., Berro A., Casale T.B. - Cultured Lung Fibroblasts from Ovalbumin-Challenged "Asthmatic" Mice Differ Functionally from Normal, Am. J. Respir Cell Mol Biol, Vol 37, pp 424-430, 2007 